\title{
The Long Way from Complex Phenotypes to Genes: The Story of Rat Chromosome 4 and Its Behavioral Effects
}

\author{
Gabriela Ferreira de Medeiros ${ }^{1,2}$, Fernanda Junkes Corrêa1, María Elisa Corvino', \\ Geison de Souza Izídio' ${ }^{1}$ André Ramos ${ }^{1}$ \\ ${ }^{1}$ Laboratório de Genética do Comportamento, Departamento de Biologia Celular, Embriologia e Genética, \\ Universidade Federal de Santa Catarina, Florianópolis, Brazil \\ ${ }^{2}$ Univ Bordeaux, Nutrition \& Neurobiologie Intégrée (NutriNeuro), Bordeaux, France \\ Email: g.izidio@ufsc.br
}

Received 2 May 2014; revised 31 May 2014; accepted 5 June 2014

Copyright (C) 2014 by authors and Scientific Research Publishing Inc.

This work is licensed under the Creative Commons Attribution International License (CC BY). http://creativecommons.org/licenses/by/4.0/

c) (†) Open Access

\begin{abstract}
Quantitative trait loci (QTLs) mapping has been performed during the past decades in an attempt to identify genes, gene products and mechanisms underlying numerous quantitative traits. It's a strategy based on natural variations in genes and gene products, which facilitates translation from animal models to human clinical conditions. Our team has shown that the inbred rat strains Lewis (LEW) and Spontaneously Hypertensive Rats (SHR) differ with respect to several emotionalityrelated behaviors, one of which (inner locomotion in the open field) was strongly influenced by a QTL (Anxrr16) on rat chromosome 4. Since then, several other studies not only corroborated the initial description of Anxrr16, but also extrapolated its effects to a broader context (rats from both sexes and regardless of the estrous cycle phase) and suggested that this same region influences other emotionality-related behaviors as well as alcohol intake. Other QTLs affecting neurobiological traits were also found on rat chromosome 4 and several candidate genes have been pointed out as possibly influencing those phenotypes. Altogether, these studies suggest that rat chromosome 4 constitutes an interesting target for the study of the molecular bases of anxiety and other traits related to emotional reactivity.
\end{abstract}

\section{Keywords}

Rat Chromosome 4, QTL Anxrr16, Emotionality-Related Behaviors, Alcohol Consumption, Stress-Response 


\section{Introduction}

The natural and continuous interindividual variation observed in several phenotypes is typically attributed to the effects of multiple genes in interaction with the environment. Such phenotypes are frequently referred to as "quantitative traits" and the genomic regions that contribute to their variation are known as quantitative trait loci (QTLs) [1]. QTLs mapping has been performed during the past two and a half decades in an attempt to identify genes, gene products and mechanisms underlying numerous phenotypes of interest [2]. In order to begin a typical QTLs analysis, parental strains (usually inbred) that differ genetically for the trait of interest are required [3]. Then, the simplest ways to perform this mapping are from either F2 (derived from F1 hybrids) or backcross (derived from a cross between F1 and one of the parents) generations, although F2 experiments are more commonly used [4]. Thereafter, the phenotype and genotype of many individuals of the selected generation (e.g. F2) are scored. Briefly, this method identifies chromosome (Chr.) regions that are most likely associated with the phenotype of interest in a given population [2].

The pioneer studies on QTLs mapping stemmed from agricultural research (Figure 1), where this technique has an enormous practical potential, more specifically aiming at identifying genomic regions related to growth, flavor or disease resistance. In this context, the first QTLs analysis was carried out in the tomato [5]. Later, this strategy has spread out into other research fields. In rodents, the first QTL was mapped in 1991, when investigators found evidence suggesting the presence of a blood pressure regulatory locus on rat Chr. 10 [6]. Regarding behavioral phenotypes, Flint et al. [7] were the first authors to find QTLs in mice, identifying three loci contributing to the genetic variance of emotionality. Moisan et al. [8] described for the first time a behavioral QTL in rats, identifying a locus on Chr. 8 related to motor activity. A few years later, Ramos et al. [9] mapped, for the first time, a genomic region influencing an emotionality-related trait in rats. This genomic region, first named Ofil1 (open field inner locomotion 1), was located on rat Chr. 4 and was originally described as influencing locomotion in the inner area of the open field test (OF), a putative experimental index of anxiety. Since then, several studies have mapped different QTLs in both rats and mice for numerous phenotypes including bone inflammation [10], blood glucose levels [11], locomotion [12], alcohol preference [13], blood corticosterone levels [14], novelty/stress-induced locomotor activation [15], HDL-cholesterol level [16], radiation susceptibility [17], brain inflammation [18], stress response [19] and circadian rhythms [20]. Differently from knockout and transgenic approaches, this strategy is based on natural variations in genes and gene products that physiologically modulate the trait of interest, in a manner that may ultimately facilitate translation from animal models to human clinical conditions.

\section{Identification of the First Emotionality-Related QTL in the Rat}

In a seminal study involving six inbred rat strains, Ramos et al. [21] proposed that the Lewis (LEW) and

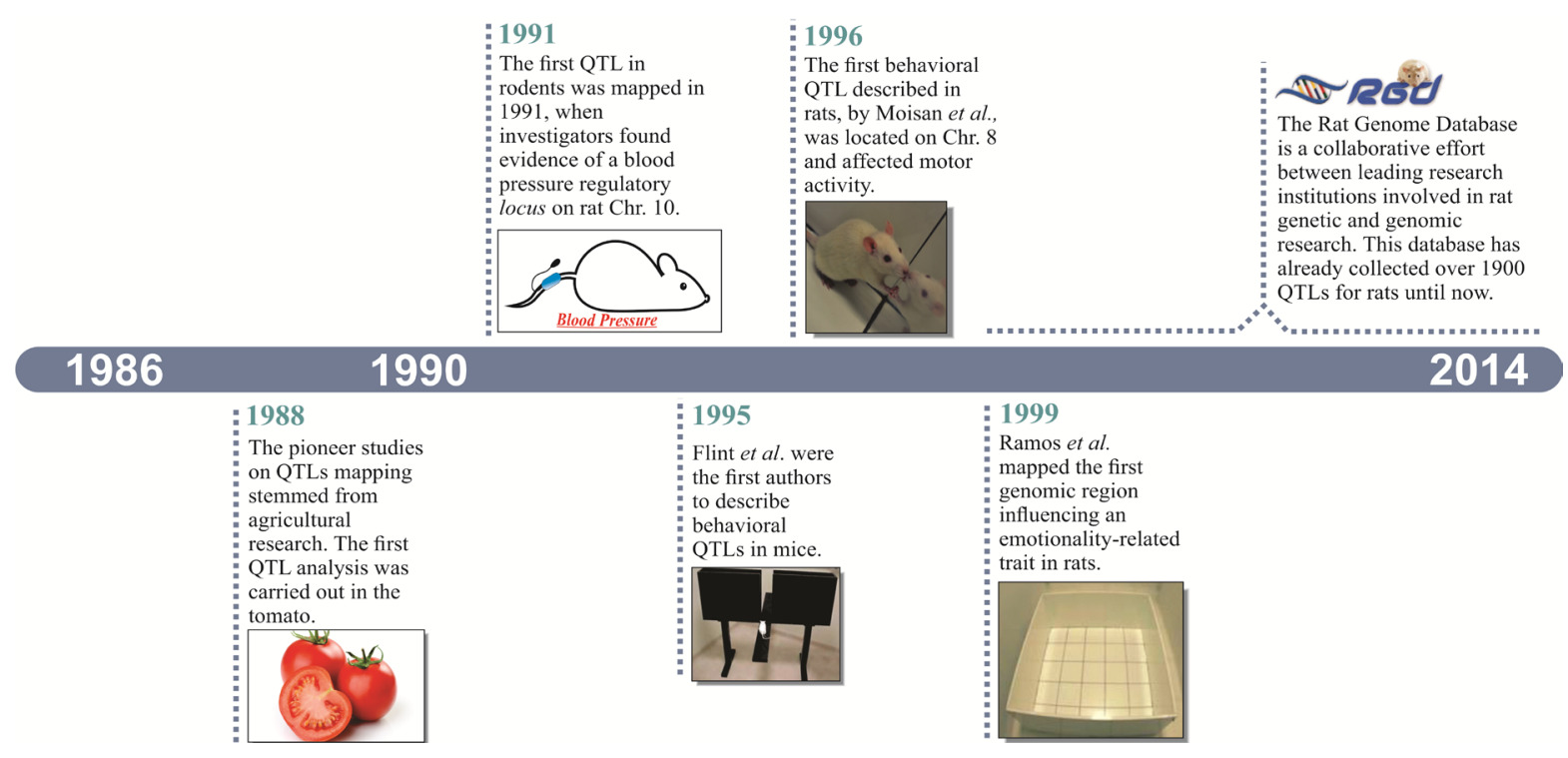

Figure 1. Historical landmarks in QTLs studies. 
Spontaneously Hypertensive Rats (SHR) inbred strains constituted a useful genetic model for the study of emotionality. These strains display contrasting responses when tested in several behavioral models of emotionality, with LEW rats being more "anxious-like" than SHR rats. These two strains showed significant differences in the inner locomotion in the OF, although they did not differ in their levels of general locomotion. A subsequent study by Ramos et al. [22] has corroborated these behavioral differences between strains and investigated some of their inheritance mechanisms, confirming that these behavioral contrasts were mainly genetic in their origin.

Aiming at investigating the genetic basis of these emotionality-related differences, a genome-wide QTLs search, using LEW and SHR rats, was carried out by Ramos et al. [9]. This study, as mentioned above, identified and mapped a QTL located on rat Chr. 4 affecting inner locomotion in the OF, which remains today as the second strongest QTL ever reported for anxiety in rats (maximum LOD score of 7. 22). This QTL was originally named Ofil1 [9], but it is currently denominated Anxrr16 (Anxiety related response QTL 16) in the Rat Genome Database [23]. Originally, Anxrr16 was found to affect only females and in a counterintuitive manner, that is, LEW alleles conferred the offspring a higher rather than a lower locomotion score in the inner area of the OF [9]. Such a counterintuitive phenomenon is not rare in QTLs studies, since the F2 reflects genetic remixing of the two parental strains and can reveal new genetic combinations [19] [24] [25]. Interestingly, LEW alleles in Anxrr16 conferred the offspring an even higher OF inner locomotion than that displayed by the parental SHR strain, showing that this major QTL had also a transgressive effect. Initially, this study revealed that Anxrr16 was not only sex-specific, but also depended on the type of cross (LEW or SHR grandmother) [9].

A few years later, independent researchers conducted QTLs analyses based on the intercross of different sets of contrasting strains for ethanol consumption, which led to the identification of regions, also on rat Chr. 4, that influenced alcohol preference [26] [27]. These studies suggested that this genomic region might have a pleiotropic effect; influencing not only emotional reactivity but also ethanol consumption and possibly other stressrelated phenotypes. Moreover, this region was found to harbor several other neurobiological QTLs, which supports the relevance of such a region, as discussed throughout this review.

\section{Complexities and Limitations of QTLs Studies}

As several other methodologies, QTLs mapping also has its limitations. For example, QTLs analysis requires large sample sizes, and the mapped loci normally account for only a small fraction of the total genetic variation in the population. Moreover, these experiments are arduous and rarely lead to individual genes [2] [28] as a QTL may contain many genes that contribute to the phenotype of interest. In addition, sometimes several linked genes are responsible for the genetic variation of a trait, and it is hard to differ if there are one or more QTLs contributing for the trait [29].

Nevertheless, there are successful stories in the field of QTLs mapping. In a review, Flint et al. [2] highlighted some studies that have led to the identification of underlying genes. However, if we look carefully at these studies, we will see that the genes identified had unusually large effect sizes. Furthermore, in some cases, QTLs have been found to be context dependent, with their effects diverging in magnitude and/or direction in different backgrounds, different environments or between males and females. This type of effect can be a major concern, since estimates of allelic effects would be valid only under specific situations, and interferences due to laboratory conditions might render some results invalid on a wide range of natural environments [30]. Beyond that, the statistical tests for evaluating the significance of a QTL are numerous and many tests can produce false positive results. A commonly adopted solution is to use permutation analysis to estimate a threshold value, which is valid for small samples [2] [29] [31]-[33].

In the field of neurobiological disorders, mapping behaviors derived from anxiety-related tests alone may be extremely complex, as anxiety disorders are multifactorial and the consequence of a combination of genetic and environmental factors [34]. A practical example of the complexity of QTLs mapping is a study by FernandezTeruel et al. [35], where the authors identified eight QTLs, three of which (on Chr. 5, 10, and 15) influenced more than one behavioral measure of fear in an F2 cross of Roman High and Low avoidance rats. When comparing these results with those from a similar study by Gershenfeld and Paul [36], but using mice instead of rats, no apparent overlap in the location of the QTLs was shown when comparing the syntenic regions between species. In other words, studies using the same animal models of anxiety but using different species or strains can show different results in terms of QTL location. These findings show that anxiety-related traits as well as the techniques used to model these disorders are complex and still far from being completely understood. 


\section{Further Studies on Anxrr16}

Despite the complexity and limitations intrinsic to QTLs studies, the remarkable strength of Anxrr16 has inspired our team to persevere in the study of this genome region and its associated phenotypes. Doubts have been raised regarding the replicability, the pattern of inheritance, and the ethological meaning of this QTL [28] [32]. A series of subsequent studies have helped us to look more closely at these matters. A study carried out by Mormède et al. [37] used F4 and F5 generations from a LEW x SHR intercross, selected through molecular markers at both Anxrr16 and Anxrr17 (another QTL for OF inner locomotion, located on Chr. 7 and previously called Ofil2). This selection led to a "high line"-which had alleles increasing inner locomotion in the OF, i.e. LEW alleles at Anxrr16 and SHR alleles at Anxrr17-and a "low line"-with the inverse phenotype/genotype. They found that the high line was more active than the low line in the OF. It was also observed that the inhibition of locomotor activity in the low line (as compared to the high line) was directly related to the aversiveness of the situation (larger in the center than in the periphery of the OF, and under strong than under dim light conditions), and this effect was more intense in males than in females [37]. This study was the first one to reproduce Anxrr16's effects in the OF after its description in 1999, despite its limitation in dissociating the magnitude of each of the QTLs' effect (Anxrr16 and Anxrr17). It has also revealed a potential effect of Anxrr16 in males, which wasn't originally observed by Ramos et al. [9]. Using a similar methodology, Vendruscolo et al. [38] have confirmed this QTL's effects on OF inner locomotion in rats deriving from an F2 intercross between the LEW and the SHR strains. Identically to Ramos et al. [9] (but not to Mormède et al. [37]), they have found that this effect was restricted to females. Interestingly, this study has also revealed an effect of Anxrr16 on ethanol $10 \%$ intake of female rats, with SHR alleles increasing the alcohol consumption (in the expected sense, since SHR rats have a higher ethanol intake than LEW rats). This work suggested that the Anxrr16 region could contain either linked genes with independent influences on anxiety-related responses and ethanol consumption, or a pleiotropic gene with simultaneous effects on both traits.

Another study performed by Vendruscolo et al. [39], has shown that this region of rat Chr. 4 additionally affects stress-induced analgesia, which was evaluated in the hot-plate task after TMT (2,4,5-trimethylthiazoline, a component of fox feces) exposure, but in male rats only. Curiously, no difference regarding this phenotype was found between both parental strains. The authors suggested that behaviors measured in classical models of generalized anxiety and reactivity to stress produced by predator odors could be genetically dissociated.

Two years later, Hameister and colleagues [40] investigated if this same QTL was also effective in the Floripa $\mathrm{H}$ and $\mathrm{L}$ rat lines. These lines derived from a genetically heterogeneous stock and were selectively bred for high $(\mathrm{H})$ and low $(\mathrm{L})$ levels of locomotion in the inner area of the OF. They have found that the selection for this phenotype has acted on the genotype frequencies of two markers flanking the Anxrr16 region. This finding suggests that this region's influence on anxiety-related phenotypes is not only relevant to animals derived from the specific parental strains LEW and SHR, but it also proved to be important for other populations of laboratory rats, standing out as a promising target to be investigated in other animal species, including humans. In 2009, Chiavegatto et al. [41] have investigated the potential molecular and physiological links between $\alpha$-synuclein protein and the behavioral differences observed between LEW and SHR strains. $\alpha$-synuclein is widely expressed in the central nervous system, it downregulates the synthesis of dopamine and has been shown to be involved in neurodegenerative disorders and alcoholism (both conditions potentially having anxiety as a common feature) [42]-[48]. Snca, the gene encoding for $\alpha$-synuclein, is mapped on Chr. 4 near the Anxrr16 region and was pointed as a positional candidate gene. This study reported increased $\alpha$-synuclein mRNA and protein expression and decreased dopaminergic activity in the hippocampus of LEW rats when compared to SHR. It has also identified a single nucleotide polymorphism in the $\alpha$-synuclein-coding gene that might be responsible for the difference in this gene's expression between the strains and that could therefore be leading to their behavioral differences regarding OF inner locomotion and ethanol consumption [41]. A latter study by Vendruscolo et al. [49] revealed that Anxrr16 also influences the induction of cocaine sensitization. In an F3 population derived from a LEW $\times$ SHR intercross, male rats carrying SHR alleles in this region were more sensitive than the ones carrying LEW alleles. The hypothalamic-pituitary-adrenocortical (HPA) axis is one of the biological mediators of the acute effects of psychostimulants and of the development of sensitization, also being proposed to influence the development of other psychiatric disorders, notably anxiety and depression [50]-[53]. Once again, the Anxrr16 locus was shown to influence a behavioral trait possibly related to stress and emotional reactivity [49].

More recently, Izídio et al. [33] performed a new extensive QTLs analysis focused on rat Chr. 4 in an F2 gen- 
eration derived from a LEW $\times$ SHR intercross. This analysis, besides identifying five different QTLs linked to emotional and ethanol intake behaviors in male F2 rats, also confirmed Anxrr16's location and its effects in both males and females. Regarding the female rats, a separated analysis was carried out and suggested that Anxrr16 effects may depend on the estrous cycle. This was the first study confirming the existence of Anxrr16's effects through an independent QTLs analysis, as in the original study by Ramos et al. [9]. It has also confirmed the remarkable strength of this QTL, which explained 14\% of the variance in males [33].

Taken together, these studies corroborate the initial description of Anxrr16. In addition, they show that this QTL is also present in male rats, that its detection in female rats might be conditioned by their estrous cycle and that it may also be relevant to other rat strains. Furthermore, they suggest that this same region influences other emotionality-related behaviors as well as alcohol intake and, therefore, it might contain one (pleiotropic) or more (linked) genes influencing these different behaviors. Finally, the biological meaning of these effects (i.e. do all these traits share a common neurobiological substrate or are they independent phenotypes?) and the fine mapping of the Anxrr16 region still need to be further explored.

\section{The Congenic Strain SLA16}

In order to shed some light on these remaining issues, de Medeiros et al. [54] began the development of a congenic strain, which would allow us to refine the location and isolate the effect of Anxrr16 as well as to dissect the effects of this whole chromosome region and all of its potential QTLs. In this new strain, named SHR.LEWAnxrr16 (abbreviated as SLA16), a piece of Chr. 4 containing the Anxrr16 region was transferred from the LEW strain into the SHR genome. To our knowledge, this was the first report of an anxiety-related locus being isolated in the genome of rats through the construction of a congenic strain. We hypothesized that the scores of inner locomotion in the OF of these congenic animals would be even higher than those from the parental strain SHR, due to the counterintuitive and transgressive nature of this locus. After five arduous years of selective breeding, the congenic SLA16 strain allowed us to confirm the location of Anxrr16 on Chr. 4, within a region of 86.3 Mpb between the molecular markers D4Rat76 and D4Mgh11 (see Figure 2). SLA16 rats showed higher scores of inner locomotion in the OF when compared to SHR controls, which was observable in both sexes, did not depend on the estrous cycle and was present under different lighting conditions. The anxiolytic-like effects of LEW alleles in Anxrr16 were corroborated in other anxiety paradigms, which vary in the nature and intensity of anxiogenic stimuli, such as the light/dark box, the T-maze and the triple test. Our results also confirmed the counterintuitive and transgressive nature of its effects, with the anxiety levels of the new congenic animals being reduced to an even lower level than those found in the parental SHR strain. Since SLA16 animals also presented higher locomotion in different unfamiliar environments (as the periphery of the OF and an activity cage for $1 \mathrm{~h}$ ), we could not discard the possibility that Anxrr16 was modulating, to some extent, something other than anxiety (e.g. motor activity). Nevertheless, after $22.5 \mathrm{~h}$ of habituation in the activity cages as well as in their home-cages, no strain difference regarding locomotor activity was found, suggesting that Anxrr16 modulates emotional reactivity to novel environments rather than spontaneous motor activity [54].

For being a much "cleaner" tool when compared to the hybrid populations used in the previous studies, the congenic strain SLA16 may have made possible the detection of genetic differences that could not be consistently detected before. This new tool is also the bottom line for the development of congenic sub-lines, which will allow the dissection and further reduction of the size of this Chr. segment. Furthermore, studies involving comparative genomics, gene expression, and validation of candidate genes shall lead to the discovery of the molecular pathways underlying the behaviors influenced by Anxrr16.

\section{Rat Chromosome 4 and Its Neurobiological-Related QTLS}

Several studies of genetic mapping allowed the identification of genomic regions influencing different neurobiological traits on rat Chr. 4, such as alcohol consumption [13] [27], stress response [55] and anxiety-related behavior [9] (Table 1). By using the alcohol-preferring (P) and alcohol-nonpreferring (NP) rat lines, Carr et al. [56] reported a QTL near Anxrr16 influencing alcohol consumption, which was later confirmed in a study by Bice et al. [13]. Moreover, Terenina-Rigaldie et al. [27] found a QTL on rat Chr. 4 affecting anxiety-related behaviors in an F2 derived from High-Ethanol Preferring (HEP) and WKY lines. Furthermore, Potenza et al. [14] described a QTL, also on Chr. 4, controlling corticosterone levels. In addition, many QTLs not related to neurobiological traits were identified on rat Chr. 4, such as for bone mineral density [57], blood pressure [58] and body 


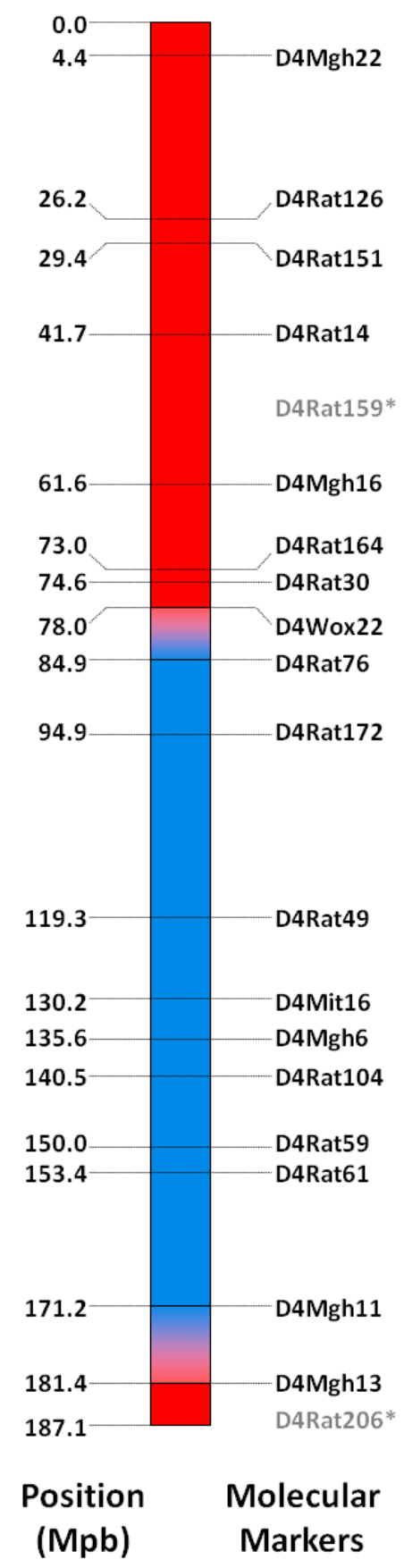

Figure 2. Schematic representation of allele frequencies in the congenic strain SLA16-The red areas represent portions of the genome where over $97 \%$ of the alleles came from the SHR strain, whereas the blue area is completely constituted by LEW alleles and the transition areas (where both alleles are found in variable proportions) are represented by a blue/red gradient. (*) indicates two molecular markers for which the positions in Mpb are not available on the Rat Genome Database, and had their locations estimated from their position in Centimorgan.

weight [59], among others [23]. These findings suggest that Chr. 4 constitutes an interesting target for the study of the molecular bases of anxiety and other traits related to stress and emotional reactivity.

\section{Candidates Genes on Chromosomes 4}

Regarding the several QTLs listed in Table 1, different genes may be implicated in regulating the different 
Table 1. Significant QTLs for neurobiological traits mapped on rat chromosome 4.

\begin{tabular}{|c|c|c|c|c|c|c|c|c|c|c|}
\hline Name $^{*}$ & Symbol & Trait & Sub Trait & LOD & LRS & Strains & Gender & Start ${ }^{*}$ & Stop ${ }^{*}$ & Reference \\
\hline $\begin{array}{l}\text { Alcohol } \\
\text { consumption } \\
\text { QTL 14 }\end{array}$ & Alc14 & $\begin{array}{l}\text { Consumption } \\
\text { level }\end{array}$ & $\begin{array}{l}\text { Alcohol 5\% } \\
\text { consumption }\end{array}$ & 7.6 & - & HEPxWKY & $\mathrm{M}, \mathrm{F}$ & 58421110 & 158108528 & [27] \\
\hline $\begin{array}{l}\text { Alcohol } \\
\text { consumption } \\
\text { QTL 18 }\end{array}$ & Alc18 & $\begin{array}{c}\text { Consumption } \\
\text { level }\end{array}$ & $\begin{array}{c}\text { Alcohol } \\
\text { preference }\end{array}$ & 9.2 & - & PxNP & $\mathrm{M}, \mathrm{F}$ & 54828166 & 152570244 & [13] [26] \\
\hline $\begin{array}{l}\text { Alcohol } \\
\text { consumption } \\
\text { QTL } 21\end{array}$ & Alc 21 & $\begin{array}{c}\text { Consumption } \\
\text { level }\end{array}$ & $\begin{array}{c}\text { Alcohol } \\
\text { consumption }\end{array}$ & 8.6 & - & PxNP & $\mathrm{M}, \mathrm{F}$ & 54879077 & 127941994 & [13] \\
\hline $\begin{array}{c}\text { Anxiety related } \\
\text { response QTL } \\
16\end{array}$ & Anxrr16 & Anxiety response & $\begin{array}{c}\text { Inner } \\
\text { locomotion OF }\end{array}$ & 7.22 & - & LEWxSHR & $\mathrm{F}$ & 96498821 & 1711204377 & [9] \\
\hline $\begin{array}{c}\text { Anxiety related } \\
\text { response QTL } \\
29\end{array}$ & Anxrr29 & Anxiety response & $\begin{array}{c}\text { Inner } \\
\text { locomotion OF }\end{array}$ & - & 14.4 & LEWXSHR & M & 106808891 & 151808891 & [33] \\
\hline $\begin{array}{c}\text { Anxiety related } \\
\text { response QTL } \\
30\end{array}$ & Anxrr30 & Anxiety response & Defecation OF & - & 14.5 & LEWXSHR & M & 62386644 & 107386644 & [33] \\
\hline $\begin{array}{l}\text { Anxiety related } \\
\text { response QTL } \\
32\end{array}$ & Anxrr32 & Anxiety response & $\begin{array}{l}\text { Locomotion in } \\
\text { light LDB }\end{array}$ & - & 14.3 & LEWXSHR & M & 148704454 & 187126005 & [33] \\
\hline $\begin{array}{c}\text { Anxiety related } \\
\text { response QTL } \\
33\end{array}$ & Anxrr33 & Anxiety response & $\begin{array}{l}\text { Time in light } \\
\text { LDB }\end{array}$ & - & 10.4 & LEWXSHR & M & 148704454 & 187126005 & [33] \\
\hline $\begin{array}{c}\text { Anxiety related } \\
\text { response QTL } \\
34\end{array}$ & Anxrr34 & Anxiety response & $\begin{array}{l}\text { Time in dark } \\
\text { LDB }\end{array}$ & - & 17.4 & LEWXSHR & M & 148704454 & 187126005 & [33] \\
\hline NR & - & Anxiety response & Forced ethanol & - & 10.8 & LEWXSHR & M & - & - & [33] \\
\hline $\begin{array}{c}\text { Anxiety related } \\
\text { response QTL } \\
35\end{array}$ & Anxrr35 & $\begin{array}{l}\text { Anxiety } \\
\text { response }\end{array}$ & Defecation OF & - & 14.3 & LEWXSHR & F (D-P) & 6913861 & 51913861 & [33] \\
\hline NR & - & $\begin{array}{l}\text { Anxiety } \\
\text { response }\end{array}$ & $\begin{array}{l}\text { Locomotion in } \\
\text { dark LDB }\end{array}$ & - & 9.9 & LEWXSHR & F (D-P) & - & - & [33] \\
\hline NR & - & $\begin{array}{l}\text { Anxiety } \\
\text { response }\end{array}$ & $\begin{array}{l}\text { Time in light } \\
\text { LDB }\end{array}$ & - & 15.2 & LEWXSHR & $\mathrm{F}(\mathrm{E}-\mathrm{M})$ & - & - & [33] \\
\hline NR & - & $\begin{array}{l}\text { Anxiety } \\
\text { response }\end{array}$ & $\begin{array}{l}\text { Locomotion in } \\
\text { light LDB }\end{array}$ & - & 13.3 & LEWXSHR & F (E-M) & - & - & [33] \\
\hline $\begin{array}{c}\text { Stress } \\
\text { Responsive } \\
\text { Adrenal Weight } \\
\text { QTL 3 }\end{array}$ & Sradr3 & $\begin{array}{c}\text { Hypothalamic } \\
\text { pituitary-adrenal } \\
\text { axis }\end{array}$ & $\begin{array}{l}\text { Adrenal gland } \\
\text { weight }\end{array}$ & 6.19 & - & WKYxF344 & $\mathrm{M}, \mathrm{F}$ & 56690161 & 101690161 & [81] \\
\hline $\begin{array}{c}\text { Stress response } \\
\text { QTL } 4\end{array}$ & Stresp4 & Hormone level & Corticosterone & - & 19.0 & LEWxF344 & $\mathrm{M}, \mathrm{F}$ & 47889730 & 14560340 & [55] \\
\hline
\end{tabular}

*Data obtained from Rat Genome Database (RGD); NR=QTL not registered in the RGD database; LRS= likelihood ratio statistic; LOD= logarithm of odds; F= Female; M= Male; D-P = Diestreus-Proestreus phases of the estrous cycle; E-M = Estreus-metestreus phases of the estrous cycle; OF = open field; LDB = light-dark box; Start/Stop = number of base pairs in the chromosome map.

behavioral traits associated to rat Chr. 4. The neuropeptide Y gene (Npy) is expressed mainly in the amygdala and in the hippocampus, and might be associated to these behavioral traits. The encoded protein (NPY) has been shown to have anxiolytic properties and to participate in the control of appetite. Also, Npy expression was shown to be decreased in anxious rats and in rats displaying high alcohol consumption [60] [61].

Other interesting candidate is the aforementioned Snca gene, that maps in the Anxrr16 QTL region [41]. Snca encodes the $\alpha$-synuclein protein that is widely expressed in the central nervous system [62], abundant in dopamine neurons and has been associated with Parkinson's disease [63]. Even though the overexpression of this protein can result in dopamine neuron dysfunction [64], it is known that the underexpression of Snca may play a role in stress-related increases in alcohol drinking [65]. Liang et al. [46] proposed that differential expression of Snca may contribute to alcohol preference in inbred alcohol-preferring rats and its relevance was confirmed by different techniques [46] [66] [67]. Moreover, as mentioned before, Chiavegatto et al. [41] found differences in both the Snca gene and protein expression in the hippocampus of LEW and SHR rats, which might underlie the anxiety-related differences in their behavior. 
The corticotropin releasing hormone receptor 2 gene (Crhr2) encodes a G protein-coupled receptor that influences stress, anxiety and alcohol consumption [68] [69]. In humans, it has been suggested that single-nucleotide polymorphisms in this gene could interact with both childhood sexual abuse and emotional neglect to influence decision-making [70] [71]. A possible role of Crhr2 in alcohol consumption was also suggested in a study using knockout mice [72]. More recently, differences were observed in the expression of Crhr2 in the amygdala, hypothalamus and caudate-putamenof the inbred P (iP) and NP (iNP)rats. In accordance with the study involving the Crhr2 knockout mice [50], Crhr2 expression was lower in iP rats and it was associated to increased levels of alcohol consumption and anxiety when compared with iNP rats [73].

Another gene of interest is Grip2, which encodes the Glutamate Receptor-Interacting Protein2 (GRIP2). Grip2 is widely expressed in the cerebral cortex, hippocampus and olfactory bulb, in synaptic plasma membrane and postsynaptic density fractions [74]. It was observed that GRIP2 interacts with the subunits GluA2 and GluA3 of the AMPA receptor [74] [75], which regulates long term potentiation (LTP) and long term depression (LTD) involved in the cellular bases for learning and memory [76]-[78]. The expression and maintenance of LTP and LTD are believed to be a result of the insertion and internalization of AMPA receptors at the postsynaptic membrane [79]. Different studies suggest that the GRIP2 protein can act as a scaffold to anchor AMPA receptor in the synapses [75] [80].

As discussed in this review, several QTLs analyses using different animal models have led to the identification of genomic regions on rat Chr. 4 related to different behavioral traits, such as anxiety-like and alcohol consumption behaviors. These findings support the relevance of rat Chr. 4 in the modulation of neurobiological traits, and suggest that one or more genes located in this region might be responsible for the variation observed in emotionality-related behaviors in rats. As aforementioned, our group identified a QTL affecting inner locomotion in the OF, a putative experimental index of anxiety. With the development of a congenic strain (SLA16) for this region, it is now possible to carry out a sequence analysis of the whole locus, as well as to use microarrays to look for differential expression and to test positional candidate genes influencing this phenotype. Furthermore, subcongenic strains can be developed to further reduce this region and help us to better understand which genes are involved in this specific or in the other correlated phenotypes. Different approaches based on the analysis of interference RNA and on behavioral phenotyping will be used to determine the influence of certain gene products on the interindividual variation in the OF inner locomotion. Also, the use of receptor antagonists

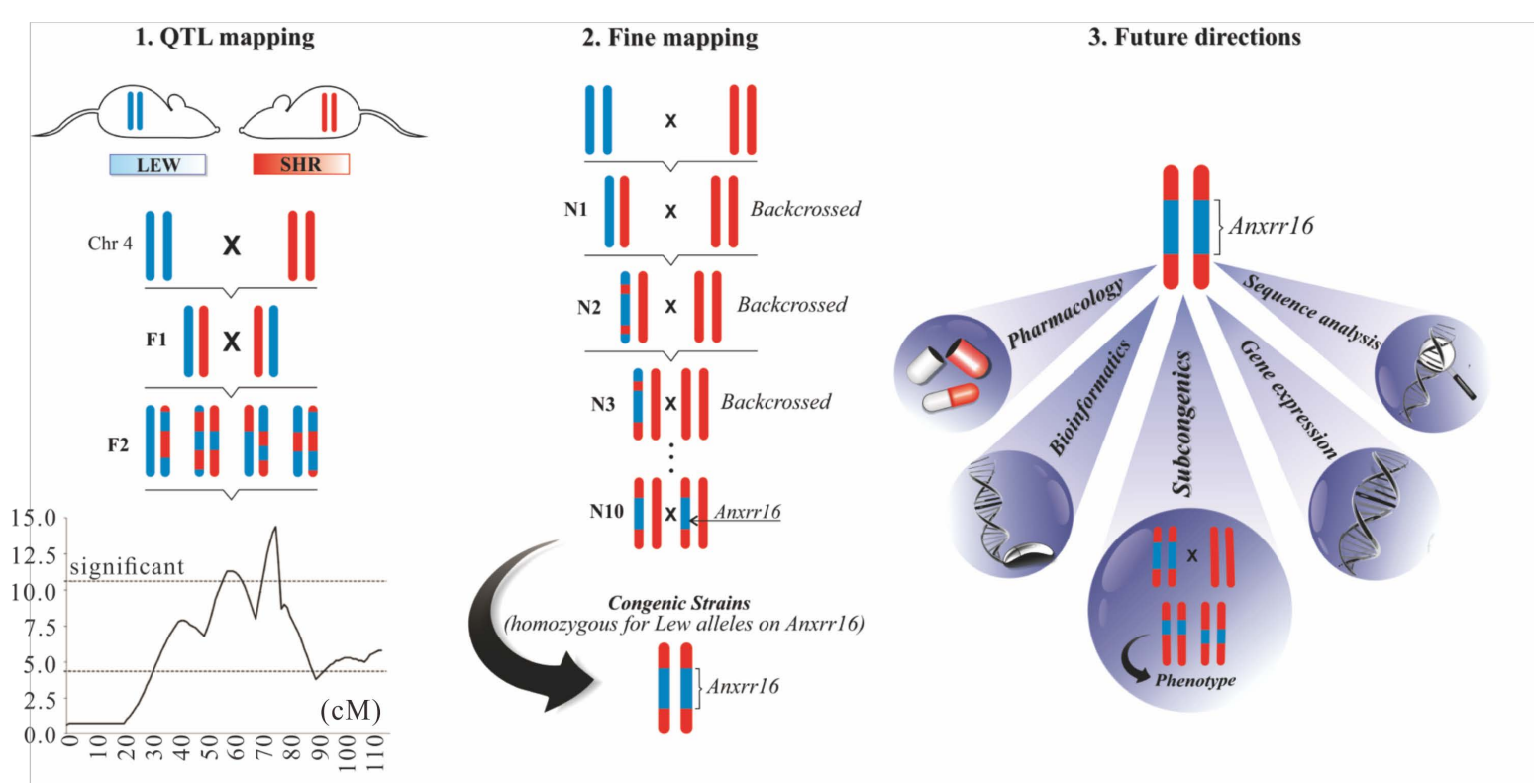

Figure 3. From QTLs to genes. 1) Two inbred rat strains that differ in open field locomotion were interrossed, a genomewide QTLs search was carried out and a QTL was mapped on chromosome 4; 2) After obtaining an F1 (or N1) generation, the animals were backcrossed to SHR rats for 10 generations and genotyped to select heterozygous animals for the Anxrr16 region, after which Anxrr16 heterozygous rats were intercrossed. The congenic strain is homozygous for LEW alleles in the Anxrr16 region and about 99.9\% homozigous SHR in the rest of the genome and 3) Next steps that will help us to investigate positional candidate genes influencing relevant neurobiological traits. 
and agonists in pharmacological investigations will help us to better understand these complex neurobiological traits (Figure 3) and ultimately to identify genes, DNA variants and their role in the development of some human psychological traits and disorders.

\section{Acknowledgements}

The authors wish to thank Daniel Tiago Barbosa for his valuable help in the development of the figures.

\section{References}

[1] Plomin, R., Owen, M.J. and McGuffin, P. (1994) The Genetic Basis of Complex Human Behaviors. Science, 264, 1733-1739. http://dx.doi.org/10.1126/science.8209254

[2] Flint, J., Valdar, W., Shifman, S. and Mott, R. (2005) Strategies for Mapping and Cloning Quantitative Trait Genes in Rodents. Nature Reviews Genetic, 6, 271-286. http://dx.doi.org/10.1038/nrg1576

[3] Mauricio, R. (2001) Mapping Quantitative Trait Loci in Plants: Uses and Caveats for Evolutionary Biology. Nature Reviews Genetic, 2, 370-381. http://dx.doi.org/10.1038/35072085

[4] Moore, K.J. and Nagle, D.L. (2000) Complex Trait Analysis in the Mouse: The Strengths, the Limitations and the Promise yet to Come. Annual Review of Genetics, 34, 653-686. http://dx.doi.org/10.1146/annurev.genet.34.1.653

[5] Paterson, A.H., Lander, E.S., Hewitt, J.D., Peterson, S., Lincoln, S.E. and Tanksley, S.D. (1988) Resolution of Quantitative Traits into Mendelian Factors by Using a Complete Linkage Map of Restriction Fragment Length Polymorphisms. Nature, 335, 721-726. http://dx.doi.org/10.1038/335721a0

[6] Hilbert, P., Lindpaintner, K., Beckmann, J.S., Serikawa, T., Soubrier, F., Dubay, C., Cartwright, P., De Gouyon, B., Julier, C., Takahasi, S., et al. (1991) Chromosomal Mapping of Two Genetic Loci Associated with Blood-Pressure Regulation in Hereditary Hypertensive Rats. Nature, 353, 521-529. http://dx.doi.org/10.1038/353521a0

[7] Flint, J., Corley, R., DeFries, J.C., Fulker, D.W., Gray, J.A., Miller, S. and Collins, A.C. (1995) A Simple Genetic Basis for a Complex Psychological Trait in Laboratory Mice. Science, 269, 1432-1435. http://dx.doi.org/10.1126/science.7660127

[8] Moisan, M.P., Courvoisier, H., Bihoreau, M.T., Gauguier, D., Hendley, E.D., Lathrop, M., James, M.R. and Mormede, P. (1996) A Major Quantitative Trait Locus Influences Hyperactivity in the WKHA Rat. Nature Genetics, 14, 471-473. http://dx.doi.org/10.1038/ng1296-471

[9] Ramos, A., Moisan, M.P., Chaouloff, F., Mormede, C. and Mormede, P. (1999) Identification of Female-Specific QTLs Affecting an Emotionality-Related Behavior in Rats. Molecular Psychiatry, 4, 453-462. http://dx.doi.org/10.1038/sj.mp.4000546

[10] Remmers, E.F., Longman, R.E., Du, Y., O’Hare, A., Cannon, G.W., Griffiths, M.M. and Wilder, R.L. (1996) A Genome Scan Localizes Five Non-Mhc Loci Controlling Collagen-Induced Arthritis in Rats. Nature Genetics, 14, 82-85. http://dx.doi.org/10.1038/ng0996-82

[11] Aitman, T.J., Gotoda, T., Evans, A.L., Imrie, H., Heath, K.E., Trembling, P.M., Truman, H., Wallace, C.A., Rahman, A., Dore, C., Flint, J., Kren, V., Zidek, V., Kurtz, T.W., Pravenec, M. and Scott, J. (1997) Quantitative Trait Loci for Cellular Defects in Glucose and Fatty Acid Metabolism in Hypertensive Rats. Nature Genetics, 16, 197-201. http://dx.doi.org/10.1038/ng0697-197

[12] Conti, L.H., Jirout, M., Breen, L., Vanella, J.J., Schork, N.J. and Printz, M.P. (2004) Identification of Quantitative Trait Loci for Anxiety and Locomotion Phenotypes in Rat Recombinant Inbred Strains. Behavior Genetics, 34, 93-103. http://dx.doi.org/10.1023/B:BEGE.0000009479.02183.1f

[13] Bice, P., Foroud, T., Bo, R., Castelluccio, P., Lumeng, L., Li, T.K. and Carr, L.G. (1998) Genomic Screen for QTLs Underlying Alcohol Consumption in the P and NP Rat Lines. Mammalian Genome, 9, 949-955. http://dx.doi.org/10.1007/s003359900905

[14] Potenza, M.N., Brodkin, E.S., Joe, B., Luo, X., Remmers, E.F., Wilder, R.L., Nestler, E.J. and Gelernter, J. (2004) Genomic Regions Controlling Corticosterone Levels in Rats. Biological Psychiatry, 55, 634-641. http://dx.doi.org/10.1016/j.biopsych.2003.11.005

[15] Gill, K.J. and Boyle, A E. (2005) Quantitative Trait Loci for Novelty/Stress-Induced Locomotor Activation in Recombinant Inbred (RI) and Recombinant Congenic (RC) Strains of Mice. Behavioural Brain Research, 161, 113-124. http://dx.doi.org/10.1016/j.bbr.2005.01.013

[16] Leduc, M.S., Blair, R.H., Verdugo, R.A., Tsaih, S.W., Walsh, K., Churchill, G.A. and Paigen, B. (2012) Using Bioinformatics and Systems Genetics to Dissect HDL-Cholesterol Genetics in an MRL/MpJ $\times$ SM/J Intercross. Journal of Lipid Research, 53, 1163-1175. http://dx.doi.org/10.1194/jlr.M025833 
[17] Tsuji, A.B., Sugyo, A., Ogiu, T., Sagara, M., Kimura, T., Ishikawa, A., Sudo, H., Ohtsuki, M., Aburatani, H., Imai, T. and Harada, Y.N. (2005) Fine Mapping of Radiation Susceptibility and Gene Expression Analysis of LEC Congenic Rat Lines. Genomics, 86, 271-279. http://dx.doi.org/10.1016/j.ygeno.2005.05.007

[18] Marta, M., Stridh, P., Becanovic, K., Gillett, A., Ockinger, J., Lorentzen, J.C., Jagodic, M. and Olsson, T. (2010) Multiple Loci Comprising Immune-Related Genes Regulate Experimental Neuroinflammation EAE-Regulating QTLs on RN04. Genes \& Immunity, 11, 21-36. http://dx.doi.org/10.1038/gene.2009.62

[19] Llamas, B., Contesse, V., Guyonnet-Duperat, V., Vaudry, H., Mormede, P. and Moisan, M.P. (2005) QTL Mapping for Traits Associated with Stress Neuroendocrine Reactivity in Rats. Mammalian Genome, 16, 505-515. http://dx.doi.org/10.1007/s00335-005-0022-2

[20] Hofstetter, J.R., Mayeda, A.R., Possidente, B. and Nurnberger Jr., J.I. (1995) Quantitative Trait Loci (QTL) for Circadian Rhythms of Locomotor Activity in Mice. Behavior Genetics, 25, 545-556. http://dx.doi.org/10.1007/BF02327578

[21] Ramos, A., Berton, O., Mormede, P. and Chaouloff, F. (1997) A Multiple-Test Study of Anxiety-Related Behaviours in Six Inbred Rat Strains. Behavioural Brain Research, 85, 57-69. http://dx.doi.org/10.1016/S0166-4328(96)00164-7

[22] Ramos, A., Mellerin, Y., Mormede, P. and Chaouloff, F. (1998) A Genetic and Multifactorial Analysis of AnxietyRelated Behaviours in Lewis and SHR Intercrosses. Behavioural Brain Research, 96, 195-205. http://dx.doi.org/10.1016/S0166-4328(98)00023-0

[23] Laulederkind, S.J., Hayman, G.T., Wang, S.J., Smith, J.R., Lowry, T.F., Nigam, R., Petri, V., De Pons, J., Dwinell, M.R. and Shimoyama, M. (2013) The Rat Genome Database 2013-Data, Tools and Users. Briefings in Bioinformatics, 14, 520-526. http://dx.doi.org/10.1093/bib/bbt007

[24] Caldarone, B., Saavedra, C., Tartaglia, K., Wehner, J.M., Dudek, B.C. and Flaherty, L. (1997) Quantitative Trait Loci Analysis Affecting Contextual Conditioning in Mice. Nature Genetics, 17, 335-337. http://dx.doi.org/10.1038/ng1197-335

[25] Silva, G.J., Pereira, A.C., Krieger, E.M. and Krieger, J.E. (2007) Genetic Mapping of a New Heart Rate QTL on Chromosome 8 of Spontaneously Hypertensive Rats. BMC Medical Genetics, 8, 17. http://dx.doi.org/10.1186/1471-2350-8-17

[26] Carr, L.G., Foroud, T., Bice, P., Gobbett, T., Ivashina, J., Edenberg, H., Lumeng, L. and Li, T.K. (1998) A Quantitative Trait Locus for Alcohol Consumption in Selectively Bred Rat Lines. Alcoholism: Clinical and Experimental Research, 22, 884-887. http://dx.doi.org/10.1111/j.1530-0277.1998.tb03883.x

[27] Terenina-Rigaldie, E., Moisan, M.P., Colas, A., Beauge, F., Shah, K.V., Jones, B.C. and Mormede, P. (2003) Genetics of Behaviour: Phenotypic and Molecular Study of Rats Derived From High- and Low-Alcohol Consuming Lines. Pharmacogenetics, 13, 543-554. http://dx.doi.org/10.1097/00008571-200309000-00003

[28] Flint, J. (2002) Genetic Effects on an Animal Model of Anxiety. FEBS Letters, 529, 131-134. http://dx.doi.org/10.1016/S0014-5793(02)03190-3

[29] Abiola, O., Angel, J.M., Avner, P., Bachmanov, A.A., Belknap, J.K., Bennett, B., Blankenhorn, E.P., Blizard, D.A., Bolivar, V., Brockmann, G.A., Buck, K.J., Bureau, J.F., Casley, W.L., Chesler, E.J., Cheverud, J.M., Churchill, G.A., Cook, M., Crabbe, J.C., Crusio, W.E., Darvasi, A., De Haan, G., Dermant, P., Doerge, R.W., Elliot, R.W., Farber, C.R., Flaherty, L., Flint, J., Gershenfeld, H., Gibson, J.P., Gu, J., Gu, W., Himmelbauer, H., Hitzemann, R., Hsu, H.C., Hunter, K., Iraqi, F.F., Jansen, R.C., Johnson, T.E., Jones, B.C., Kempermann, G., Lammert, F., Lu, L., Manly, K.F., Matthews, D.B., Medrano, J.F., Mehrabian, M., Mittlemann, G., Mock, B.A., Mogil, J.S., Montagutelli, X., Morahan, G., Mountz, J.D., Nagase, H., Nowakowski, R.S., O’Hara, B.F., Osadchuk, A.V., Paigen, B., Palmer, A.A., Peirce, J.L., Pomp, D., Rosemann, M., Rosen, G.D., Schalkwyk, L.C., Seltzer, Z., Settle, S., Shimomura, K., Shou, S., Sikela, J.M., Siracusa, L.D., Spearow, J.L., Teuscher, C., Threadgill, D.W., Toth, L.A., Toye, A.A., Vadasz, C., Van Zant, G., Wakeland, E., Williams, R.W., Zhang, H.G. and Zou, F. (2003) The Nature and Identification of Quantitative Trait Loci: A Community’s View. Nature Reviews Genetics, 4, 911-916. http://dx.doi.org/10.1038/nrg1206

[30] Mackay, T.F., Stone, E.A. and Ayroles, J.F. (2009) The Genetics of Quantitative Traits: Challenges and Prospects. Nature Reviews Genetics, 10, 565-577. http://dx.doi.org/10.1038/nrg2612

[31] Doerge, R.W. and Churchill, G.A. (1996) Permutation Tests for Multiple Loci Affecting a Quantitative Character. Genetics, 142, 285-294.

[32] Flint, J. (2003) Analysis of Quantitative Trait Loci that Influence Animal Behavior. Journal of Neurobiology, 54, 46-77. http://dx.doi.org/10.1002/neu.10161

[33] Izidio, G.S., Oliveira, L.C., Oliveira, L.F., Pereira, E., Wehrmeister, T.D. and Ramos, A. (2011) The Influence of Sex and Estrous Cycle on QTL for Emotionality and Ethanol Consumption. Mammalian Genome, 22, 329-340. http://dx.doi.org/10.1007/s00335-011-9327-5

[34] Hovatta, I. and Barlow, C. (2008) Molecular Genetics of Anxiety in Mice and Men. Annals of Medicine, 40, 92-109. http://dx.doi.org/10.1080/07853890701747096 
[35] Fernandez-Teruel, A., Escorihuela, R.M., Gray, J.A., Aguilar, R., Gil, L., Gimenez-Llort, L., Tobena, A., Bhomra, A., Nicod, A., Mott, R., Driscoll, P., Dawson, G.R. and Flint, J. (2002) A Quantitative Trait Locus Influencing Anxiety in the Laboratory Rat. Genome Research, 12, 618-626. http://dx.doi.org/10.1101/gr.203402

[36] Gershenfeld, H.K. and Paul, S.M. (1997) Mapping Quantitative Trait Loci for Fear-Like Behaviors in Mice. Genomics, 46, 1-8. http://dx.doi.org/10.1006/geno.1997.5002

[37] Mormede, P., Moneva, E., Bruneval, C., Chaouloff, F. and Moisan, M.P. (2002) Marker-Assisted Selection of a NeuroBehavioural Trait Related to Behavioural Inhibition in the SHR Strain, an Animal Model of ADHD. Genes, Brain and Behavior, 1, 111-116. http://dx.doi.org/10.1034/j.1601-183X.2002.10206.x

[38] Vendruscolo, L.F., Terenina-Rigaldie, E., Raba, F., Ramos, A., Takahashi, R.N. and Mormede, P. (2006) Evidence for a Female-Specific Effect of a Chromosome 4 Locus on Anxiety-Related Behaviors and Ethanol Drinking in Rats. Genes, Brain and Behavior, 5, 441-450. http://dx.doi.org/10.1111/j.1601-183X.2005.00177.x

[39] Vendruscolo, L.F., Terenina-Rigaldie, E., Raba, F., Ramos, A., Takahashi, R.N. and Mormede, P. (2006) A QTL on Rat Chromosome 7 Modulates Prepulse Inhibition, a Neuro-Behavioral Trait of ADHD, in a Lewis X SHR Intercross. Behavioral and Brain Functions, 2, 21. http://dx.doi.org/10.1186/1744-9081-2-21

[40] Hameister, T.M., Izidio, G.S., Valiati, V.H. and Ramos, A. (2008) Association of a Locus on Rat Chromosome 4 with Anxiety-Related Behaviors in Two Selectively Bred Rat Lines. Genetics and Molecular Biology, 31, 843-849. http://dx.doi.org/10.1590/S1415-47572008000500008

[41] Chiavegatto, S., Izidio, G.S., Mendes-Lana, A., Aneas, I., Freitas, T.A., Torrao, A.S., Conceicao, I.M., Britto, L.R. and Ramos, A. (2009) Expression of $\alpha$-Synuclein Is Increased in the Hippocampus of Rats with High Levels of Innate Anxiety. Molecular Psychiatry, 14, 894-905. http://dx.doi.org/10.1038/mp.2008.43

[42] Mori, F., Tanji, K., Yoshimoto, M., Takahashi, H. and Wakabayashi, K. (2002) Immunohistochemical Comparison of Alpha- and Beta-Synuclein in Adult Rat Central Nervous System. Brain Research, 941, 118-126.

[43] Perez, R.G., Waymire, J.C., Lin, E., Liu, J.J., Guo, F. and Zigmond, M.J. (2002) A Role for Alpha-Synuclein in the Regulation of Dopamine Biosynthesis. Journal of Neuroscience, 22, 3090-3099.

[44] Kaplan, B., Ratner, V. and Haas, E. (2003) $\alpha$-Synuclein: Its Biological Function and Role in Neurodegenerative Diseases. Journal of Molecular Neuroscience, 20, 83-92. http://dx.doi.org/10.1385/JMN:20:2:83

[45] Bonsch, D., Reulbach, U., Bayerlein, K., Hillemacher, T., Kornhuber, J. and Bleich, S. (2004) Elevated Alpha Synuclein Mrna Levels Are Associated with Craving in Patients with Alcoholism. Biological Psychiatry, 56, 984-986. http://dx.doi.org/10.1016/j.biopsych.2004.09.016

[46] Liang, T., Spence, J., Liu, L., Strother, W.N., Chang, H.W., Ellison, J.A., Lumeng, L., Li, T.K., Foroud, T. and Carr, L.G. (2003) $\alpha$-Synuclein Maps to a Quantitative Trait Locus for Alcohol Preference and Is Differentially Expressed in Alcohol-Preferring and -Nonpreferring Rats. Proceedings of the National Academy of Sciences of the United States of America, 100, 4690-4695. http://dx.doi.org/10.1073/pnas.0737182100

[47] Richard, I.H. (2005) Anxiety Disorders in Parkinson’s Disease. Advances in Neurology, 96, 42-55.

[48] Morris, E.P., Stewart, S.H. and Ham, L.S. (2005) The Relationship between Social Anxiety Disorder and Alcohol Use Disorders: A Critical Review. Clinical Psychology Review, 25, 734-760. http://dx.doi.org/10.1016/j.cpr.2005.05.004

[49] Vendruscolo, L.F., Vendruscolo, J.C., Terenina, E., Ramos, A., Takahashi, R.N. and Mormede, P. (2009) Marker-Assisted Dissection of Genetic Influences on Motor and Neuroendocrine Sensitization to Cocaine in Rats. Genes, Brain and Behavior, 8, 267-274. http://dx.doi.org/10.1111/j.1601-183X.2008.00465.X

[50] Cador, M., Dulluc, J. and Mormede, P. (1993) Modulation of the Locomotor Response to Amphetamine by Corticosterone. Neuroscience, 56, 981-988. http://dx.doi.org/10.1016/0306-4522(93)90144-5

[51] Przegalinski, E., Filip, M., Siwanowicz, J. and Nowak, E. (2000) Effect of Adrenalectomy and Corticosterone on Cocaine-Induced Sensitization in Rats. Journal of Physiology and Pharmacology, 51, 193-204.

[52] Rivet, J.M., Stinus, L., Lemoal, M. and Mormede, P. (1989) Behavioral Sensitization to Amphetamine Is Dependent on Corticosteroid Receptor Activation. Brain Research, 498, 149-153. http://dx.doi.org/10.1016/0006-8993(89)90411-3

[53] Mello, A.F., Mello, M.F., Carpenter, L.L. and Price, L.H. (2003) Update on Stress and Depression: The Role of the Hypothalamic-Pituitary-Adrenal (HPA) Axis. Revista Brasileira de Psiquiatria, 25, 231-238. http://dx.doi.org/10.1590/S1516-44462003000400010

[54] De Medeiros, G.F., Pereira, E., Granzotto, N. and Ramos, A. (2013) Low-Anxiety Rat Phenotypes Can Be Further Reduced through Genetic Intervention. PLoS ONE, 8, Article ID: e83666. http://dx.doi.org/10.1371/journal.pone.0083666

[55] Potenza, M.N., Brodkin, E.S., Joe, B., Luo, X., Remmers, E.F., Wilder, R.L., Nestler, E.J. and Gelernter, J. (2004) Genomic Regions Controlling Corticosterone Levels in Rats. Biological Psychiatry, 55, 634-641. http://dx.doi.org/10.1016/j.biopsych.2003.11.005 
[56] Carr, L.G., Foroud, T., Bice, P., Gobbett, T., Ivashina, J., Edenberg, H., Lumeng, L. and Li, T.K. (1998) A Quantitative Trait Locus for Alcohol Consumption in Selectively Bred Rat Lines. Alcoholism: Clinical and Experimental Research, 22, 884-887. http://dx.doi.org/10.1111/j.1530-0277.1998.tb03883.x

[57] Koller, D.L., Liu, L., Alam, I., Sun, Q., Econs, M.J., Foroud, T. and Turner, C.H. (2008) Linkage Screen for BMD Phenotypes in Male and Female COP and DA Rat Strains. Journal of Bone and Mineral Research, 23, 1382-1388. http://dx.doi.org/10.1359/jbmr.080401

[58] Garrett, M.R., Joe, B., Dene, H. and Rapp, J.P. (2002) Identification of Blood Pressure Quantitative Trait Loci that Differentiate Two Hypertensive Strains. Journal of Hypertension, 20, 2399-2406. http://dx.doi.org/10.1097/00004872-200212000-00019

[59] Kloting, N., Wilke, B. and Kloting, I. (2005) Alleles on Rat Chromosome 4 (D4Got41-Fabp1/Tacr1) Regulate Subphenotypes of Obesity. Obesity Research, 13, 589-595. http://dx.doi.org/10.1038/oby.2005.63

[60] Ehlers, C.L., Li, T.K., Lumeng, L., Hwang, B.H., Somes, C., Jimenez, P. and Mathe, A.A. (1998) Neuropeptide Y Levels in Ethanol-Naive Alcohol-Preferring and Nonpreferring Rats and in Wistar Rats after Ethanol Exposure. Alcoholism: Clinical and Experimental Research, 22, 1778-1782. http://dx.doi.org/10.1111/j.1530-0277.1998.tb03979.x

[61] Stewart, R.B., Gatto, G.J., Lumeng, L., Li, T.K. Andmurphy, J.M. (1993) Comparison of Alcohol-Preferring (P) and Nonpreferring (NP) Rats on Tests of Anxiety and for the Anxiolytic Effects of Ethanol. Alcohol, 10, 1-10. http://dx.doi.org/10.1016/0741-8329(93)90046-Q

[62] Mori, F., Nishie, M., Kakita, A., Yoshimoto, M., Takahashi, H. and Wakabayashi, K. (2006) Relationship among $\alpha$ Synuclein Accumulation, Dopamine Synthesis, and Neurodegeneration in Parkinson Disease Substantia Nigra. Journal of Neuropathology \& Experimental Neurology, 65, 808-815. http://dx.doi.org/10.1097/01.jnen.0000230520.47768.1a

[63] Polymeropoulos, M.H., Higgins, J.J., Golbe, L.I., Johnson, W.G., Ide, S.E., Di Iorio, G., Sanges, G., Stenroos, E.S., Pho, L.T., Schaffer, A.A., Lazzarini, A.M., Nussbaum, R.L. and Duvoisin, R.C. (1996) Mapping of a Gene for Parkinson's Disease to Chromosome 4q21-q23. Science, 274, 1197-1199. http://dx.doi.org/10.1126/science.274.5290.1197

[64] Kurz, A., Double, K.L., Lastres-Becker, I., Tozzi, A., Tantucci, M., Bockhart, V., Bonin, M., Garcia-Arencibia, M., Nuber, S., Schlaudraff, F., Liss, B., Fernandez-Ruiz, J., Gerlach, M., Wullner, U., Luddens, H., Calabresi, P., Auburger, G. and Gispert, S. (2010) A53T-Alpha-Synuclein Overexpression Impairs Dopamine Signaling and Striatal Synaptic Plasticity in Old Mice. PLoS ONE, 5, Article ID: E11464. http://dx.doi.org/10.1371/journal.pone.0011464

[65] Le-Niculescu, H., Mcfarland, M.J., Ogden, C.A., Balaraman, Y., Patel, S., Tan, J., Rodd, Z.A., Paulus, M., Geyer, M.A., Edenberg, H.J., Glatt, S.J., Faraone, S.V., Nurnberger, J.I., Kuczenski, R., Tsuang, M.T. and Niculescu, A.B. (2008) Phenomic, Convergent Functional Genomic, and Biomarker Studies in a Stress-Reactive Genetic Animal Model of Bipolar Disorder and Co-Morbid Alcoholism. American Journal of Medical Genetics Part B, 147B, 134-166. http://dx.doi.org/10.1002/ajmg.b.30707

[66] Carr, L.G., Kimpel, M.W., Liang, T., Mcclintick, J.N., Mccall, K., Morse, M. and Edenberg, H.J. (2007) Identification of Candidate Genes for Alcohol Preference by Expression Profiling of Congenic Rat Strains. Alcoholism: Clinical and Experimental Research, 31, 1089-1098. http://dx.doi.org/10.1111/j.1530-0277.2007.00397.x

[67] Spence, J., Liang, T., Foroud, T., Lo, D. and Carr, L. (2005) Expression Profiling and QTL Analysis: A Powerful Complementary Strategy in Drug Abuse Research. Addiction Biology, 10, 47-51. http://dx.doi.org/10.1080/13556210412331308958

[68] Greetfeld, M., Schmidt, M.V., Ganea, K., Sterlemann, V., Liebl, C. and Muller, M.B. (2009) A Single Episode of Restraint Stress Regulates Central Corticotrophin-Releasing Hormone Receptor Expression and Binding in Specific Areas of the Mouse Brain. Journal of Neuroendocrinology, 21, 473-480. http://dx.doi.org/10.1111/j.1365-2826.2009.01865.x

[69] Heilig, M. and Koob, G.F. (2007) A Key Role for Corticotropin-Releasing Factor in Alcohol Dependence. Trends in Neuroscience, 30, 399-406. http://dx.doi.org/10.1016/j.tins.2007.06.006

[70] Guillaume, S., Perroud, N., Jollant, F., Jaussent, I., Olie, E., Malafosse, A. and Courtet, P. (2013) HPA Axis Genes May Modulate the Effect of Childhood Adversities on Decision-Making in Suicide Attempters. Journal of Psychiatric Research, 47, 259-265. http://dx.doi.org/10.1016/j.jpsychires.2012.10.014

[71] Turecki, G., Ernst, C., Jollant, F., Labonte, B. and Mechawar, N. (2012) The Neurodevelopmental Origins of Suicidal Behavior. Trends in Neuroscience, 35, 14-23. http://dx.doi.org/10.1016/j.tins.2011.11.008

[72] Sharpe, A.L., Coste, S.C., Burkhart-Kasch, S., Li, N., Stenzel-Poore, M.P. and Phillips, T.J. (2005) Mice Deficient in Corticotropin-Releasing Factor Receptor Type 2 Exhibit Normal Ethanol-Associated Behaviors. Alcoholism: Clinical and Experimental Research, 29, 1601-1609. http://dx.doi.org/10.1097/01.alc.0000179371.46716.5e

[73] Yong, W., Spence, J.P., Eskay, R., Fitz, S.D., Damadzic, R., Lai, D., Foroud, T., Carr, L.G., Shekhar, A., Chester, J.A., Heilig, M. and Liang, T. (2014) Alcohol-Preferring Rats Show Decreased Corticotropin-Releasing Hormone-2 Receptor Expression and Differences in HPA Activation Compared to Alcohol-Nonpreferring Rats. Alcoholism: Clinical 
and Experimental Research, 38, 1275-1283.

[74] Srivastava, S., Osten, P., Vilim, F.S., Khatri, L., Inman, G., States, B., Daly, C., Desouza, S., Abagyan, R., Valtschanoff, J.G., Weinberg, R.J. and Ziff, E.B. (1998) Novel Anchorage of GluR2/3 to the Postsynaptic Density by the AMPA Receptor-Binding Protein ABP. Neuron, 21, 581-591. http://dx.doi.org/10.1016/S0896-6273(00)80568-1

[75] Dong, H., O’Brien, R.J., Fung, E.T., Lanahan, A.A., Worley, P.F. and Huganir, R.L. (1997) GRIP: A Synaptic PDZ Domain-Containing Protein that Interacts with AMPA Receptors. Nature, 386, 279-284. http://dx.doi.org/10.1038/386279a0

[76] Bliss, T.V. and Collingridge, G.L. (1993) A Synaptic Model of Memory: Long-Term Potentiation in the Hippocampus. Nature, 361, 31-39. http://dx.doi.org/10.1038/361031a0

[77] Malenka, R.C. and Bear, M.F. (2004) LTP and LTD: An Embarrassment of Riches. Neuron, 44, 5-21. http://dx.doi.org/10.1016/j.neuron.2004.09.012

[78] Martin, S.J., Grimwood, P.D. and Morris, R.G. (2000) Synaptic Plasticity and Memory: An Evaluation of the Hypothesis. Annual Review of Neuroscience, 23, 649-711. http://dx.doi.org/10.1146/annurev.neuro.23.1.649

[79] Malinow, R. and Malenka, R.C. (2002) AMPA Receptor Trafficking and Synaptic Plasticity. Annual Review of Neuroscience, 25, 103-126. http://dx.doi.org/10.1146/annurev.neuro.25.112701.142758

[80] Osten, P., Khatri, L., Perez, J.L., Kohr, G., Giese, G., Daly, C., Schulz, T.W., Wensky, A., Lee, L.M. and Ziff, E.B. (2000) Mutagenesis Reveals a Role for ABP/GRIP Binding to GluR2 in Synaptic Surface Accumulation of the AMPA Receptor. Neuron, 27, 313-325. http://dx.doi.org/10.1016/S0896-6273(00)00039-8

[81] Solberg, L.C., Baum, A.E., Ahmadiyeh, N., Shimomura, K., Li, R., Turek, F.W., Takahashi, J.S., Churchill, G.A. and Redei, E.E. (2006) Genetic Analysis of the Stress-Responsive Adrenocortical Axis. Physiological Genomics, 27, 362369. http://dx.doi.org/10.1152/physiolgenomics.00052.2006 